\title{
Biochemical changes in selected body tissues of the scallop Patinopecten yessoensis under long- term exposure to low Cd concentrations
}

\author{
Z. S. Evtushenko ${ }^{1}$, O. N. Lukyanova ${ }^{2}$ and N. K. Khristoforova ${ }^{3}$ \\ ${ }^{1}$ Laboratory of Comparative Physiology and Chemical Ecology, ${ }^{2}$ Institute of Marine Biology, Far East Science Center, \\ Academy of Sciences of the USSR, Vladivostok 690022, USSR \\ ${ }^{3}$ Laboratory of Geochemistry, Pacific Institute of Geography, Far East Science Center, Academy of Sciences of the USSR, \\ Vladivostok 690022, USSR
}

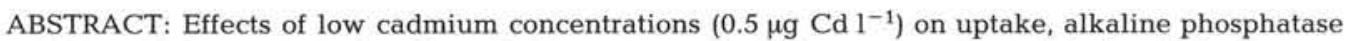
activity and zinc content of scallops Patinopecten yessoensis were investigated during $25 \mathrm{~d}$ exposure. Cadmium accumulations in digestive gland were bound to cytoplasmic intermediate molecular weight proteins. No adverse damage was observed.
\end{abstract}

\section{INTRODUCTION}

Spreading via water and air, heavy metals have become pollutants of great local, regional and even global importance; they add to the concentrations of toxic substances in environments and organisms, sometimes very distant from man's activities. High concentrations of metals (and other pollutants) in the environment is a new ecological factor to which organisms must adapt in order to survive. In recent years, effects of metals on various plant and animal species and communities as a whole have been studied intensively. Largely because of the growing interest in mariculture, it is important to understand the mechanisms by which some trace elements influence organisms and the potential adaptations to these effects in commercially important invertebrates (Carpene and George, 1981; Viarengo et al., 1981). In our region, the scallop Patinopecten (Mizuhopecten) yessoensis (Jay) has been, for some time, important for fishery and cultivation. It is a low-boreal species inhabiting Pacific coasts of Asia.

This scallop $(180 \times 170 \mathrm{~mm}$ shell $)$ has been recorded in the Sea of Japan at Primorye, North Korea, western Sakhalin, northern Honshu and Hokkaido; in the Okhotsk Sea, at Aniva Bay and Bousse Lagoon; and in the South Kuriles (Scarlato, 1976, 1981). The ability of various species of Pectinidae to accumulate large amounts of heavy metals in nature and under labora- tory conditions is well-documented (Brooks and Rumsby, 1965; Bryan, 1973; Nelson et al., 1976; Saenko et al., 1976; Pesch and Stewart, 1980; Carmichael and Fowler, 1981); however, there is little information on biochemical mechanisms of detoxication of trace elements in molluscs.

This paper presents results of a model experiment dealing with the effect of low Cd concentrations on the scallop Patinopecten yessoensis under long-term exposure. The nature of $\mathrm{Cd}$ accumulation in molluscan tissues and the binding of $\mathrm{Cd}$ with cytoplasmic proteins of the digestive gland were studied. The functional state of test animals was estimated by the activity of alkaline phosphatase in selected organs of the scallop.

\section{MATERIALS AND METHODS}

The molluscs were collected in Vityaz Bay (Peter the Great Bay, Sea of Japan; $32 \%$ salinity) in January 1982. We selected 100 to $120 \mathrm{~mm}$ long scallops, with shells free of fouling organisms. The scallops were kept in tanks with sea water, to which cadmium chloride was added at a final concentration of $0.5 \mu \mathrm{g}^{-1}$. This concentration is one-tenth of the admissible concentration of $\mathrm{Cd}$ in rivers and marine fishery areas. Duration of exposure was $25 \mathrm{~d}$. The medium was replaced every second day. Scallops were fed on water extracts of Laminaria and Ulva homoge- 
nates, and twice on yeast extracts. On Days 3, 7, 15, 20 and 25 of the experiment, 3 individuals were removed from every test and control tank, and $\mathrm{Cd}$ and $\mathrm{Zn}$ contents in gonad, mantle, digestive gland and muscle were determined. Digestive glands of test scallops were removed and examined for cytoplasmic proteins. Digestive glands were homogenized in 3 volumes of $0.05 \mathrm{M}$ Tris- $\mathrm{HCl}$ buffer at $\mathrm{pH} 7.5$. Centrifugation of homogenates was carried out at $16,000 \mathrm{~g}$ for $20 \mathrm{~min}$. Calcium and magnesium salts were added to the supernatant to precipitate mitochondria and microsomes (Kamath and Narayan, 1972). Clear supernatant was used to separate proteins. Cytosol $(5 \mathrm{ml})$ was loaded into an $80 \times 2.5 \mathrm{~cm}$ column with Sephadex G-75. Proteins were eluted with $0.05 \mathrm{M}$ Tris- $\mathrm{HCl}$ buffer ( $\mathrm{pH} 7.5$ ) at a rate of $18 \mathrm{ml} \mathrm{h}^{-1}$. The column was first calibrated with Cytochrom C (molecular weight $13,400)$, used as a marker protein for determining elution volumes of intermediate molecular weight proteins $(10,000$ to 15,000$)$. Proteins were quantified in preparations as described by Lowry et al., 1951.

Cadmium and zinc contents were measured by atomic-absorption spectrophotometry in protein fractions and in pooled samples of molluscan tissues after acid mineralization in an autoclave.

Preparations for determining alkaline phosphatase activity were obtained by centrifugation of tissue homogenates at $16,000 \mathrm{~g}$ for $20 \mathrm{~min}$. Enzyme activity was determined with P-nitrophenylphosphate as a substrate in $0.1 \mathrm{M}$ carbonate buffer, pH 9.6 (Echeteby, 1980).

\section{RESULTS}

Concentrations of cadmium and zinc from selected body tissues of the scallop are given in Table 1. Digestive glands had a high background level of $\mathrm{Cd}$, although the scallops were collected in an uncontaminated area. Cadmium contents of digestive glands ranged up to $53.6 \mu \mathrm{g} \mathrm{g}^{-1}$ dry matter; this is 20 to 30 times more than in other organs. The gills, for example, contained $8 \mu \mathrm{g} \mathrm{Cd} \mathrm{g}^{-1}$, the gonads $3.4 \mu \mathrm{g} \mathrm{Cd} \mathrm{g}^{-1}$ dry matter. Zinc content varied: $62 \mu \mathrm{g} \mathrm{g}^{-1}$ in the digestive gland and $160 \mu \mathrm{g} \mathrm{g}^{-1}$ dry matter in the mantle. Initially, Cd content of the digestive gland increased and was maximal on the 15 th day $\left(89 \mu \mathrm{g} \mathrm{g}^{-1}\right)$; it then fell sharply to $21 \mu \mathrm{g} \mathrm{g}^{-1}$. Cadmium content either increased consistently (gonads and mantle) or did not change measurably (gills and muscles).

During the experiment, $\mathrm{Zn}$ content in gills increased constantly. In digestive gland and gonads, zinc content varied with no apparent trend. It is emphasized that the highest $\mathrm{Cd}$ content in the digestive gland on Day 15 was accompanied by the lowest $\mathrm{Zn}$ concentration, but by Day 25, when the Cd content of the digestive gland fell, the $\mathrm{Zn}$ content increased.

Examination of cytoplasmic proteins for metal contents showed that cytosol contained measurable quantities of $\mathrm{Cd}$ and $\mathrm{Zn}$. Cd concentration in cytoplasmic proteins of experimentals was $0.23 \mu \mathrm{g} \mathrm{mg}^{-1}$ of protein on Day 25. Zn content of cytosol did not change significantly during the experiment.

The elution profile of cytoplasmic proteins extracted from the digestive gland of control scallops and metal contents of protein fractions are given in Fig. 1. Separation of cytosol aliquot on Sephadex G-75 gave 2 main peaks: one corresponded to high-molecular weight proteins, the other to the region of elution of Cytochrom C (molecular weight 13,400). All protein fractions had a significant $\mathrm{Zn}$ content; the highest concentration ( $2 \mu \mathrm{g} \mathrm{mg}^{-1}$ protein) was found in proteins of molecular weight of about 13,000 . However, the amount of these proteins was small (optical density 0.2 at $254 \mathrm{~nm}$ ). Cadmium distribution was different: proteins of high molecular weights were practically Cd-free, and intermediate molecular weight proteins contained the main portion of the $\mathrm{Cd}$. The highest concentrations of $\mathrm{Cd}$ and $\mathrm{Zn}$ were coincident and associated with proteins of a molecular weight of 13,000 .

Fig. 2 and 3 give elution profiles of cytoplasmic proteins extracted from scallop digestive glands on the

Table 1. Patinopecten yessoensis. Mean cadmium and zinc concentrations ( $\mu \mathrm{g} \mathrm{g}^{-1}$ dry matter) in selected organs after exposure for $25 \mathrm{~d}$ to $0.5 \mu \mathrm{g} \mathrm{Cd} 1^{-1}$

\begin{tabular}{|c|c|c|c|c|c|c|c|c|c|c|}
\hline \multirow[b]{3}{*}{ Organs } & \multirow{2}{*}{\multicolumn{2}{|c|}{$\begin{array}{c}\text { Start } \\
\text { (Day zero) }\end{array}$}} & \multicolumn{8}{|c|}{ Day } \\
\hline & & & & & & & & & & \\
\hline & $\mathrm{Cd}$ & $\mathrm{Zn}$ & $\mathrm{Cd}$ & $\mathrm{Zn}$ & $\mathrm{Cd}$ & $\mathrm{Zn}$ & $\mathrm{Cd}$ & $\mathrm{Zn}$ & $\mathrm{Cd}$ & $\mathrm{Zn}$ \\
\hline Gonad & 3.4 & 137.5 & 4.8 & 111.8 & 16.5 & 139.5 & 9.6 & 108.0 & 14.0 & 81.2 \\
\hline Mantle & 2.6 & 161.8 & 6.9 & 88.7 & 6.8 & 113.0 & 10.9 & 133.8 & 9.4 & 112.5 \\
\hline Digestive gland & 53.6 & 62.3 & 60.2 & 130.9 & 89.9 & 95.9 & $-^{*}$ & $-\cdot$ & 21.6 & 130.6 \\
\hline Gills & 8.0 & 118.6 & 13.2 & 138.5 & 8.2 & 148.6 & 10.2 & 183.6 & $-^{*}$ & $-^{*}$ \\
\hline Muscle & 1.5 & 69.4 & 1.0 & 68.3 & 1.1 & 79.3 & 1.9 & 76.8 & 2.0 & 75.1 \\
\hline
\end{tabular}


15th and 25th days of exposure, and metal concentrations of protein fractions. By Day 15, the amount of proteins containing high concentrations of $\mathrm{Cd}$ increased (Fig. 2, optical density 1.4 at $254 \mathrm{~nm}$ ). $\mathrm{Zn}$ was found in all protein fractions, Cd only in 2 fractions (Fig. 2). By Day 25, redistribution of metals was observed: Cd concentration in low-molecular proteins increased almost 2-fold to $0.7 \mu \mathrm{g} \mathrm{mg}{ }^{-1}$ proteins (Fig. 3); moreover, as in the case of the $15 \mathrm{~d}$ exposure results, a peak persisted which corresponded to a protein with significant content of this metal (in the region of elution of proteins with a molecular weight above $13,000)$. High molecular weight proteins contained insignificant amounts of both $\mathrm{Cd}$ and $\mathrm{Zn}$.

In all organs of the scallop, no sharp change of alkaline phosphatase activity was observed during the experiment (Table 2). Only in gills was there an appreciable decrease in alkaline phosphatase activity during $\mathrm{Cd}$ exposure. By the end of the experiment, the activity of this enzyme in all organs of test scallops was somewhat higher than in the controls.
Fig. 1. Patinopecten yessoensis. Gel chromatography of cytoplasmic proteins of digestive gland (control) on Sephadex G-75. 1: elution profile of cytoplasmic proteins at O.D. $254 \mathrm{~nm}$; $2: \mathrm{Zn}$ content in protein fractions; $3: \mathrm{Cd}$ content in protein fractions
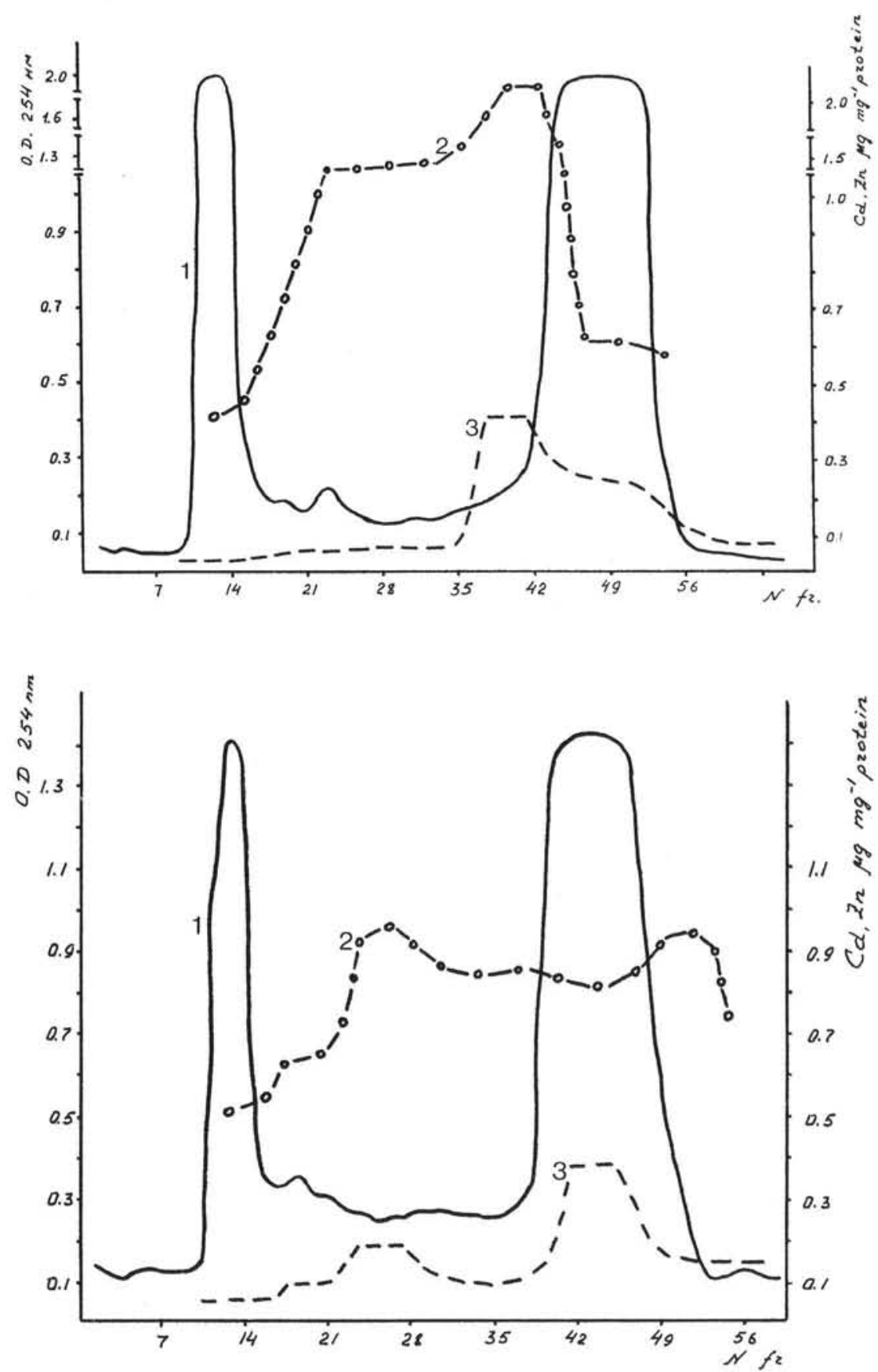

Fig. 2. Patinopecten yessoensis. Gel chromatography of cytoplasmic proteins of digestive gland (Day 15) on Sephadex G-75. 1: elution profile of cytoplasmic proteins at O.D. $254 \mathrm{~nm} ; 2: \mathrm{Zn}$ content in protein fractions; $3: \mathrm{Cd}$ content in protein fractions 


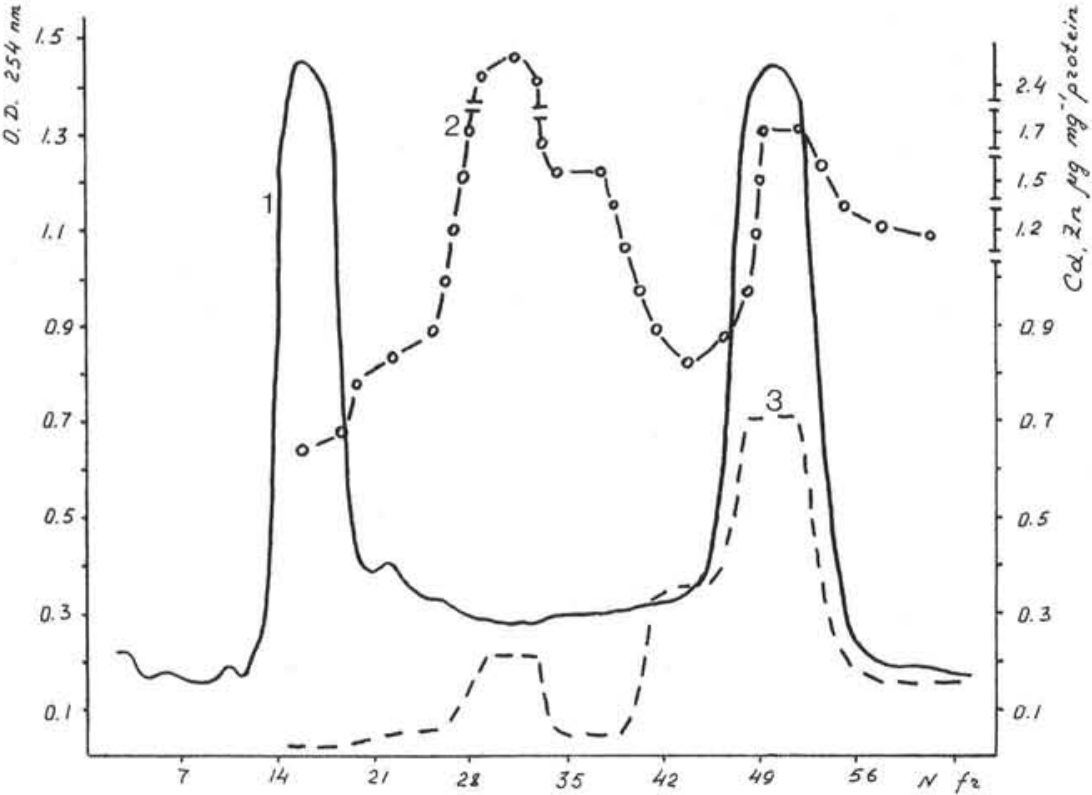

Fig. 3. Patinopecten yessoensis. Gel chromatography of cytoplasmic proteins of digestive gland (Day 25) on Sephadex G-75. 1: elution profile of cytoplasmic proteins at O.D. $254 \mathrm{~nm} ; 2: \mathrm{Zn}$ content in protein fractions; $3: \mathrm{Cd}$ content in protein fractions

Table 2. Patinopecten yessoensis. Alkaline phosphatase activity in selected tissues, during $20 \mathrm{~d}$ exposure to $0.5 \mu \mathrm{g}$ Cd $1^{-1}$. Mean values in $\mu \mathrm{mol} \mathrm{min} \mathrm{mg}^{-1} \mathrm{mg}^{-1}$ protein \pm 1 standard deviation

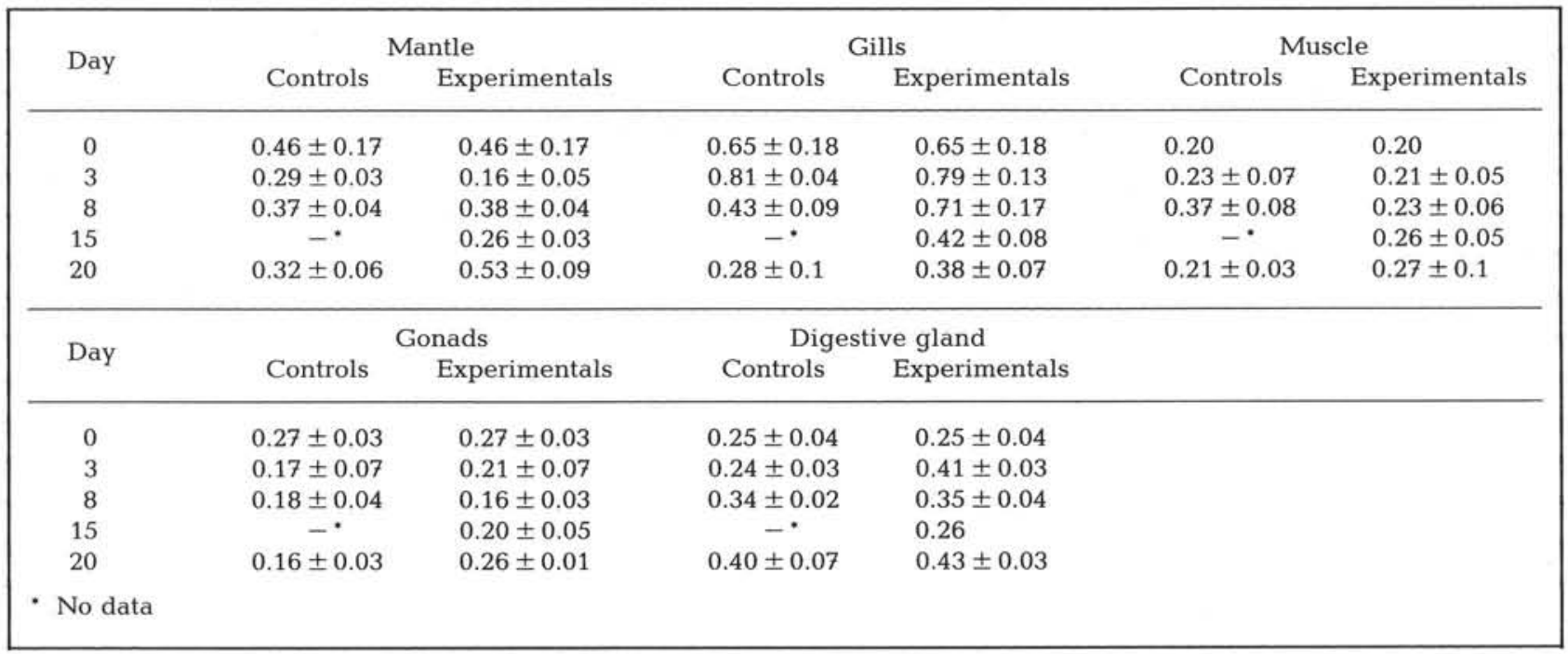

\section{DISCUSSION}

Toxicological studies on mechanisms of heavy metal influences upon organisms usually test high concentrations of heavy elements, not likely to be encountered under field conditions. In animals exposed to high heavy metal concentrations, significant changes may occur in organs and body tissues as indicated by biochemical, cytological, histological and other methods. After long-term exposure to comparatively low metal concentrations, organisms usually adapt to the new conditions, but the mechanisms by which this is accomplished are imperfectly understood. In our experiment, cadmium concentrations were only 5 times above background in the waters of Peter the Great Bay (Patin et al., 1980).

In contrast to other commercially important bivalves (oysters and mussels), the scallop Patinopecten yessoensis can accumulate in its digestive system considerable amounts of $\mathrm{Cd}$, even in a contamination-free area (Lukyanova and Evtushenko, 1982; Khristoforova, 1983). Many authors (Mullin and Riley, 1956; Brooks and Rumsby, 1965; Segar et al., 1971; Bryan, 1973; Nielsen and Nathan, 1975; Vattuone et al., 1976) find this accumulation to be typical of all molluscs of the family Pectinidae. 
We observed that scallops held at $0.5 \mu \mathrm{g} \mathrm{Cd} 1^{-1}$ for $25 \mathrm{~d}$ did not exhibit any pathological changes; this may be due to the comparatively high resistance of scallops to Cd. For example, the LC-50 for juvenile

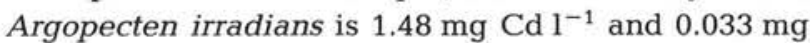
$\mathrm{Ag}^{-1}$ (Nelson et al., 1976). Pesch and Stewart (1980) found at chronic exposures of scallops to high $\mathrm{Cd}$ concentration that scallops accumulate 2,000 to $3,000 \mathrm{mg} \mathrm{Cd} \mathrm{kg}^{-1}$ dry weight, when compared to $7 \mathrm{mg}$ $\mathrm{kg}^{-1}$ for controls. Further, accumulation is greater in summer, and occurs at more rapid rates; this is typical both of scallops (Bryan, 1973) and of oysters (Zaroogian and Cheer, 1976). In the oyster, Cd accumulation rates in summer were twice those in winter. Our experiment was conducted in January, when metabolic processes in scallops were significantly retarded, and this may account for the comparatively moderate rates of $\mathrm{Cd}$ accumulation by various scallop tissues. Nevertheless, even this small variation in Cd concentration in scallop tissues caused significant alterations in the chemical binding of this element by cytoplasmic proteins. Cadmium occurred in 2 protein peaks by the 15th day of exposure, and by the 25th day Cd concentration in the protein fraction with molecular weight of 12 to 15,000 was twice that of controls (Fig. 1 to 3 ).

It is known that $\mathrm{Cd}$ is primarily accumulated by cytosol cellular fractions, where it is bound to specific proteins, metallothioneins (Webb and Cain, 1982). Moreover, some experiments showed that a significant portion of the $\mathrm{Cd}$ content may be bound in membranes or accumulated in intracellular granules (Carmichael and Fowler, 1981; Metal-binding ..., 1981). Profiles of Cd levels in protein cytoplasmic fractions indicate strongly that proteins of low and intermediate molecular weights participate in Cd binding. Cadmium concentrations of $0.5 \mu \mathrm{g} \mathrm{I}^{-1}$ are quite likely to occur in natural habitats of molluscan populations; however, this concentration did not appear harmful to scallops. The capacity of cytoplasmic Cd-binding proteins apparently enables the organism to adapt readily to cadmium stress.

Our study considered not only chronic Cd effects but also variations of $\mathrm{Zn}$ content in the same experimental molluscs. $\mathrm{Zn}$ is a chemical analogue of $\mathrm{Cd}$. Due to the similarity of their chemical characteristics, these elements may compete for $\mathrm{Cd}$ binding sites.

Estimation of the functional state of molluscs by the activity of alkaline phosphatase showed that experimental scallops differed only slightly from controls. Moreover, during the $25 \mathrm{~d}$ experiment, all scallops showed a decrease in activity of the enzyme in gill tissues; this may be associated with restraint of movement in scallops maintained in tanks during the experiment.

Alkaline phosphatase contains $1 \mathrm{Zn}$ atom in its active center; substituting cadmium, copper or mercury for $\mathrm{Zn}$ decreases enzyme activity levels (Spiro, 1978 ) in experiments in vitro. Exposure to $0.5 \mu{\mathrm{g} \mathrm{Cd}{ }^{-1}}^{-1}$ caused a slight rise in alkaline phosphatase activity, suggesting a stimulation effect at low doses of $\mathrm{Cd}$ upon alkaline phosphatase activity of scallops. Patin (1979) pointed to the stimulatory effect of low doses of heavy metals on the sea organisms.

Thus, Cd concentrations of $0.5 \mu \mathrm{g}^{-1}$ did not cause pathological effects in scallops during exposure for $25 \mathrm{~d}$. We conclude that additional amounts of cadmium accumulated by the molluscan digestive gland are bound by cytoplasmic proteins of intermediate molecular weight. Small doses of the element did not inhibit alkaline phosphatase activity, on the contrary: $0.5 \mu \mathrm{g} \mathrm{Cd} \mathrm{I}^{-1}$ elevated alkaline phosphatase levels, particularly in mantle and gill tissues.

\section{LITERATURE CITED}

Brooks, R. R., Rumsby, M. G. (1965). The biogeochemistry of trace element uptake by some New Zealand bivalves. Limnol. Oceanogr. 10: 521-527

Bryan, G. W. (1973). The occurrence and seasonal variation of trace metals in the scallops Pecten maximus (L.) and Chlamys opercularis (L.). J. mar, biol, Ass. U.K. 53: 145-166

Carmichael, N. G., Fowler, B. A. (1981). Cd accumulation and toxicity with kidney of the bay scallop Argopecten irradians. Mar. Biol. 65: 35-43

Carpene, E., George, S. G. (1981). Absorption of cadmium by gills of Mytilus edulis (L.). Molecul. Physiol. 1: 23-34

Echeteby, C. O. (1980). Partial purification and characterization of intestinal alkaline phosphatase of the rainbow lizard Agama agama. Comp. Biochem. Physiol. 67 B: 41-47

Kamath, S. A., Narayan, K. A. (1972). Interaction of $\mathrm{Ca}^{2+}$ with endoplasmic reticulum of rat liver: standardized procedure for the isolation of rat liver microsomes. Analyt. Biochem. 48: 53-61

Khristoforova, N. K. (1983). Commercial molluscs of Peter the Great Bay: mineral composition of soft tissues (Russ.). In: Abstracts of papers submitted to IV All-Union Symposium on Mariculture, Vladivostok, 1983, p. 198-199

Lowry, O. H., Rosebrough, N. J., Farr, A. L., Randall, R. J, (1951). Protein measurement with the Folin phenol reagent. J. biol. Chem. 193: 265-275

Lukyanova, O. N., Evtushenko, Z. S. (1982). Metal-binding proteins and alkaline phosphatase activity in the oyster Crassostrea gigas from polluted environments (Russ.). In: Problems of rational use of commercial invertebrates: abstracts of papers submitted to III All-Union Conference, Kaliningrad, 1982, p. $118-120$

Metal-binding proteins and metal toxicity (1981). Mar. Pollut. Bull. 12: 230-231

Mullin, J. B., Riley, J. P. (1956). The occurrence of cadmium in seawater and in marine organisms and sediments. J. mar. Res. 15: 103-122

Nelson, D. A., Calabrese, A., Nelson, B. A., MacInnes, J. R., Wenzloff, D. R. (1976). Biological effects of heavy metals on juvenile bay scallops Argopecten irradians in short- 
term exposures. Bull. environ. Contam. Toxicol. 16: 275-282

Nielsen, S. A., Nathan, A. (1975). Heavy metal levels in New Zealand molluscs. N.Z. Jl mar. Freshwat. Res. 9: 467-481

Patin, S. A. (1979). Effects of pollution on biological resources and productivity of the World Ocean (Russ.). Pishchevaya Promishlennost (Food Industry Press), Moscow

Patin, S. A., Morozov, N. P., Romanteeva, A. S., Mel'nikova, R. M., Borisenko, G. S. (1980). Microelements in the ecosystem of the Sea of Japan (Russ.). Geochimiya (Geochemistry) 3: 423-429

Pesch, G. G., Stewart, N. E. (1980). Cadmium toxicity to three species of estuarine invertebrates. Mar. environ. Res. 3: 145-156

Saenko, G. N., Bel'cheva, N. N., Biryukova, T. A., Sin'kov, N. A. (1976). Concentration of heavy metals by organs of starfishes and molluscs (Russ.). Zh. obshch. Biol. (J. gen. Biol.) 37: 286-291

Scarlato, O. A. (1976). Bivalve molluscs (Russ.). In: Zhirmunsky, A. (Chief Ed.) Animals and plants of Peter the Great Bay. Nauka Press (Science), Leningrad, p. 95-106

Scarlato, O. A. (1981). Bivalve molluscs of the temperate West Pacific Ocean (Russ.). Nauka Press (Science), Leningrad
Segar, D. A., Collins, J. D., Riley, J. P. (1971). The distribution of the major and some minor elements in marine animals. Part II. Molluscs. J. mar, biol. Ass. U.K. 51: 131-136

Spiro, T. G. (1978). Phosphate transport and its activation by metal ions: alkaline phosphatase (Russ.). In: Eichhorn, G. B. Inorganic biochemistry, Vol. 2. Mir Press, Moscow, p. $624-660$

Vattuone, G. M., Griggs, K. S., Mcintyre, D. R., Littlepage, J. L., Harrison, F. L. (1976). Cadmium concentrations in rock scallops in comparison with some other species. Lawrence Livermore Lab., Univ. of California, Livermore, Nat. Tech. Inform. Serv.

Viarengo, A., Zanicchi, G., Moore, M. N., Orunesu, M. (1981). Accumulation and detoxication of copper by the mussel Mytilus galloprovincialis Lam.: a study of the subcellular distribution in the digestive gland cells. Aquat. Toxicol. 1: 147-157

Webb, M., Cain, K. (1982). Function of metallothionein. Biochem. Pharmacol. 31: 137-142

Zaroogian, G. E., Cheer, S. (1976). Accumulation of cadmium by the American oyster, Crassostrea virginica. Nature, Lond. 261: 468-410 